\title{
Variable Corticosteroid Sensitivity of Thymic Cortex and Medullary Peripheral-type Lymphoid Tissue in Myasthenia Gravis Patients: Structural and Functional Effects
}

\author{
N. WILLCOX, M. SCHLUEP†, N. SOMMER, D. CAMPANA*, \\ G. JANOSSY* A. N. BROWN*, and J. NEWSOM-DAVIS† \\ From the Departments of Neurological Science and * Immunology, Royal Free \\ Hospital School of Medicine, London NW3 2QG: National Hospital for Nervous \\ Diseases, Queen Square, London
}

Accepted 21 April 1989

\section{SUMMARY}

The thymus has been studied in myasthenia gravis patients to assess the effects of previous immunosuppression on total yields of cell suspension, immunohistology and culture responses. The reduction in cell yields by pretreatment with corticosteroid was very variable. In 16 of 32 cases, cortical, medullary and total cell numbers were all greatly reduced ('depleted cases'), whereas in the others, they were within or near the typical range for untreated myasthenics. Cortical thymocytes were even more depleted than precursor thymic blasts. Thus the interpatient differences in sensitivity to corticosteroid recently described for mature $T$ cells also affected immature cortical thymocytes and their differentiating medullary progeny.

In the medulla, mature $\left(\mathrm{CD3}^{+}\right) \mathrm{T}$ lymphocytes and germinal centres were enriched by the loss of cortex and appeared relatively healthy, but somewhat depopulated. Concomitantly, in-vitro T-cell responses to acetylcholine receptor ( $\mathrm{AChR}$ ) and production of anti-AChR antibody and total IgG by thymic cells were usually well within the typical range (assessed per $10^{6}$ cells). Moreover, the total productivity of the entire thymus was reduced almost entirely by the cellular depopulation rather than by decreased function per surviving cell. Thus the main actions of this alternate day therapy with corticosteroids were apparently on total peripheral cell numbers, and perhaps on activated cells and effector mechanisms too, and its thymic effects were inessential.

\section{INTRODUCTION}

There are few reports on the in-vivo effects of corticosteroids on human lymphoid tissues, and many unanswered questions persist. It is not clear whether these drugs act primarily on

† Present address: Department of Clinical Neurology, Institute of Molecular Medicine, University of Oxford, John Radcliffe Hospital, Oxford OX3 9DU.

‡ Present address: Service de Neurologie, CHUV, 1011 Lausanne, Switzerland.

(C) Oxford University Press 1989 
lymphocyte generation and thus on cell numbers, or on the tissue distribution or functions of the surviving cells, or on the effector mechanisms in the immunological diseases where they are so widely used. Corticosteroids are often beneficial, for example, in the autoimmune disease myasthenia gravis [1], as is thymectomy in young-onset cases [2], but the mechanisms of both effects are unclear. Furthermore, different subjects vary greatly in the sensitivity of their peripheral T lymphocytes to corticosteroids [3, 4], and it is important to know which cell types or tissues express this resistance/susceptibility in man.

In myasthenia gravis, the muscle weakness results from a reduction in the number of acetylcholine receptors (AChR) at the motor endplate caused by complement-fixing autoantibodies to them (reviewed in ref. 5). There is a special relationship with the thymus in myasthenia gravis. About 10 per cent of cases have a thymoma, and among the remainder, there are 'hyperplastic' changes in the thymic medulla in most young onset patients [6]. As the rare medullary myoid cells express AChR both in vitro [7] and in situ [8], it has been suggested that autoreactivity in myasthenia gravis is initiated within the thymus [7].

Some myasthenic patients undergo thymectomy during treatment with corticosteroid, giving us an unusual opportunity to examine its in-vivo effects. The myasthenia gravis thymus is particularly suitable for study, (a) because its cortex is one of the most steroidsensitive tissues in laboratory animals $[9,10]$, and is the primary site of $T$ lymphocyte generation. As in the normal thymus, incoming progenitors identifiable by the nuclear enzyme terminal deoxynucleotidyl transferase (TdT) generate very large numbers of immature cortical thymocytes that also express both the CD4 (helper/inducer) and CD8 ('cytotoxic/suppressor') T-cell markers. Some of these almost certainly enter the medulla and differentiate into the mature single $\mathrm{CD} 4{ }^{+}$or $\mathrm{CD}^{+} \mathrm{T}$ lymphocytes that express surface receptors for antigen (the CD3 complex) and are subsequently exported (ref. 11, reviewed in ref. 12). Furthermore (b) the myasthenia gravis thymic medulla is invaded by lymph nodetype $T$ cell areas and follicles with germinal centres [13]. These are very similar to those found in peripheral lymphoid tissues in structure [13] and in culture responsiveness too. Typically, myasthenia gravis thymus cell suspensions spontaneously synthesize anti-ACh R antibody in vitro at rates that correlate strongly with the serum anti-ACh R titre [14, 15]. Many other B cells are also present in the myasthenia gravis thymus, since pokeweed mitogen often stimulates production of high levels of total IgG and of antibody to influenza virus, for example [16]. In contrast, anti-AChR production is selectively activated in vivo, and is usually depressed by pokeweed mitogen in culture $[17,18]$.

Hence we have been able to study the effects of corticosteroids on both central and peripheral-type lymphoid tissues, and on immunohistology and total yields of thymus cells in suspension as well as on their function, using thymus from 35 myasthenia gravis patients treated with corticosteroids alone and six with azathioprine as well. All the results have been compared with those from a control panel of 75 untreated patients with myasthenia gravis.

\section{MATERIALS, METHODS AND PATIENTS}

\section{Staining of tissue sections}

Approximately 10 to 15 per cent of the thymus was used for routine histopathological examination, and for unfixed tissue blocks; six $\mu \mathrm{m}$ cryostat sections from the latter were stained by indirect immunoperoxidase or immunofluorescence techniques as described in ref. 13. Two separate blocks of thymus from each of 13 patients were analysed by an immunoperoxidase technique using the same panel of monoclonal antibodies (Mabs) to T, B and thymic epithelial cell subsets, to follicular dendritic cells, and to HLA-class II, as in ref. 19. Rabbit anti-keratin was from Dakopatts (Denmark). 
TABLE 1. Clinical features of the pretreated cases of myasthenia gravis studied

\begin{tabular}{|c|c|c|c|c|c|c|c|c|c|c|c|c|c|}
\hline \multirow{4}{*}{$\begin{array}{l}\text { Paticnt subgroup } \\
\text { (range of } \\
\text { depletion } \\
\text { indices) }\end{array}$} & \multirow{4}{*}{$\begin{array}{l}\text { Sex } \\
M / F\end{array}$} & \multicolumn{3}{|c|}{ Grade of myasthenı gravis } & \multirow{4}{*}{$\begin{array}{l}\text { Onset } \\
\text { age } \\
\text { (years) }\end{array}$} & \multirow{4}{*}{$\begin{array}{l}\text { Duration } \\
\text { of myasthenia } \\
\text { gravis (months) } \ddagger\end{array}$} & \multirow{4}{*}{$\begin{array}{l}\text { Serum } \\
\alpha-A C h R \\
\text { titre } \\
(\mathrm{nMol}) \ddagger\end{array}$} & \multicolumn{3}{|c|}{ Pretreatment } & \multirow{2}{*}{\multicolumn{3}{|c|}{$\begin{array}{l}\text { Thymus } \\
\text { pathology }\end{array}$}} \\
\hline & & \multirow{3}{*}{ Mild } & \multirow{3}{*}{ Medium } & \multirow{3}{*}{ Severe } & & & & \multicolumn{2}{|c|}{ Corticosteroids } & \multirow{3}{*}{$\begin{array}{l}\text { Azathioprine } \\
\text { Duration } \\
\text { (months) }\end{array}$} & & & \\
\hline & & & & & & & & & & & \multirow[t]{2}{*}{ Atrophic } & \multirow{2}{*}{$\begin{array}{l}\text { Normal } \\
\text { for }\end{array}$} & \multirow{2}{*}{ Hyperplastıo } \\
\hline & & & & & & & & $\begin{array}{l}\text { Dose }+ \\
(\mathrm{g})_{+}^{+}\end{array}$ & $\begin{array}{l}\text { Duration } \\
\text { (months) }\end{array}$ & & & & \\
\hline \multicolumn{14}{|l|}{$\begin{array}{l}\text { Corticosteroids alone } \\
\text { Non-depleted }\end{array}$} \\
\hline (Depletion index) - 23.5-17) & $4 / 8$ & 5 & 3 & 4 & $\begin{array}{l}28 \\
(13-38)\end{array}$ & $\begin{array}{l}60 \\
(4-360)\end{array}$ & $\begin{array}{l}77 \\
(3.5-1200)\end{array}$ & $\begin{array}{l}5.6 \\
(0.9-41)\end{array}$ & $\begin{array}{l}9.0 \\
(1-60)\end{array}$ & 0 & 3 & 2 & 8 \\
\hline $\begin{array}{l}\text { Intermediate } \\
\text { (Depletion index 18.0-31.5) }\end{array}$ & $4 / 2$ & 4 & 2 & & $\begin{array}{l}19 \\
(13-41)\end{array}$ & $\begin{array}{c}8.7^{*} \\
(4-75)\end{array}$ & $\begin{array}{l}29 \\
(0.6-75)\end{array}$ & $\begin{array}{l}4.8 \\
(09-55)\end{array}$ & $\begin{array}{l}45 \\
(2-26)\end{array}$ & 0 & 2 & 2 & 3 \\
\hline $\begin{array}{l}\text { Depleted } \\
\text { (Depletion index 33-86.5) }\end{array}$ & $3 / 14$ & 3 & 7 & 7 & $\begin{array}{l}25.9 \\
(13-40)\end{array}$ & $\begin{array}{l}11 * * \\
(1.5-20)\end{array}$ & $\begin{array}{l}15.7 \\
(0.2-680)\end{array}$ & $\begin{array}{l}21^{*} \\
\left(\begin{array}{ll}0 & 1-12.5\end{array}\right)\end{array}$ & $\begin{array}{l}40 \\
(0.2-12)\end{array}$ & 0 & 8 & 2 & 7 \\
\hline $\begin{array}{l}\text { Corticosteroids + azathioprine } \\
\text { (Depletion index 50.1-83.6) }\end{array}$ & $1 / 5$ & & 4 & 2 & $\begin{array}{l}23 \\
(15-38)\end{array}$ & $\begin{array}{l}10.5 \\
(6-184)\end{array}$ & $\begin{array}{l}31.0 \\
(3-200)\end{array}$ & $\begin{array}{l}3.6 \\
(07-94)\end{array}$ & $\begin{array}{l}2.9 \\
(1-5.5)\end{array}$ & $\begin{array}{l}3.4 \\
(1-125)\end{array}$ & 4 & 1 & 3 \\
\hline \multicolumn{14}{|l|}{$\begin{array}{l}\text { Correlation coefficient } \\
\text { vs. depletion index in }\end{array}$} \\
\hline cases given corticosteroids alon & & & & & -0.14 & $-049^{* * *}$ & -0.27 & -0.29 & -0.29 & & & & \\
\hline
\end{tabular}

** Versus non-depleted subgroup $p<0.002$ by Mann-Whitney U test. ${ }^{*} p=0.05-01$.

*** Correlation is significant $p<0.05$.

+ Cumulative total doses are given in grams.

$\ddagger$ Numbers are medians (range in parentheses. 


\section{Cell suspension studies}

Cell suspension was prepared from all the remaining tissue by mechanical disruption [17], and the total cell yield determined by a single observer. The cells were stained by indirect immunofluorescence and cultured as described in ref. 17. In most cases, the immunofluorescence-stained cells were analysed on an Ortho Systems 50 Fluorescence Activated Cell Sorter, but in a few by fluorescence microscopy. In some, two-colour immunofluorescence staining with rabbit antiterminal deoxynucleotidyl transferase (TdT, Seralab) and either Ki67 (Dakopatts) or anti-CD1 MAbs was also performed [20]. Laboratory conditions were standardized throughout as far as possible (using screened batches of fetal calf serum for cultures, and constant cell concentrations, sources of media, etc.). The radioimmunoassay for anti-AChR antibodies, and the ELISA assay for total IgG (both in culture supernatants) are described in ref. 17.

\section{T-cell proliferative responses}

Thymus cells, either unseparated or enriched for low density cells, were cultured at $10^{6}$ cells/ $\mathrm{ml}$ (with or without $10 \mu \mathrm{g} / \mathrm{ml}$ of affinity-purified AChR from Torpedo marmorata electroplax) in triplicate in round-bottomed micro wells [21]. At $72 \mathrm{~h}, 1 \mu \mathrm{Ci}$ of ${ }^{3} \mathrm{H}$ thymidine was added and, $16 \mathrm{~h}$ later, the cells were harvested and counted [21].

\section{Patients}

The study is based on 41 patients with myasthenia gravis receiving treatment with immunosuppressive drugs, and a control panel of 75 cases given anticholinesterases alone 'untreated' - all of whom underwent therapeutic thymectomy. Of the former, 35 were given corticosteroids alone (mostly on alternate days), and six received azathioprine in addition, both of which were continued until the time of surgery. Thus the last oral dose was either 24 or $48 \mathrm{~h}$ before thymectomy; in addition all received $100 \mathrm{mg}$ hydrocortisone IM one hour before surgery. Their clinical details are summarized in Table 1, where they are grouped according to treatment and thymic cell yield. Thymic histology was analysed (by $\mathbf{H}$ and $\mathrm{E}$ ) in all cases (Table 1), and immunohistology in 13. The 75 'untreated' samples were studied identically (see refs. 8, 13-19,21). For a systematic immunohistological study, 40 of these had been selected to cover a full spectrum of anti-AChR titres and durations of myasthenia gravis [19]. Seventeen thymic samples from non-myasthenic controls (ranging from four months to 44 years of age) were taken at cardiothoracic operations.

\section{RESULTS}

\section{TOTAL YIELDS OF THYMUS CELL SUSPENSION}

The total thymic cell yields from 38 immunosuppressed patients are compared in Fig. 1 with those from the 75 untreated cases which vary over a broad range, but decline significantly with age $(r=-0.58, p<0.001)$. Yields were 10 -fold below this range in the six cases receiving corticosteroids and azathioprine, and in many given corticosteroids alone (Fig. 1). To quantitate these reductions, we define a 'depletion index' as the vertical distance of each point below the regression line for the untreated cases; its scale is logarithmic, a value of 40 being a 10 -fold depletion.

Two main findings emerge. First, in the 32 patients who received corticosteroids alone, the 


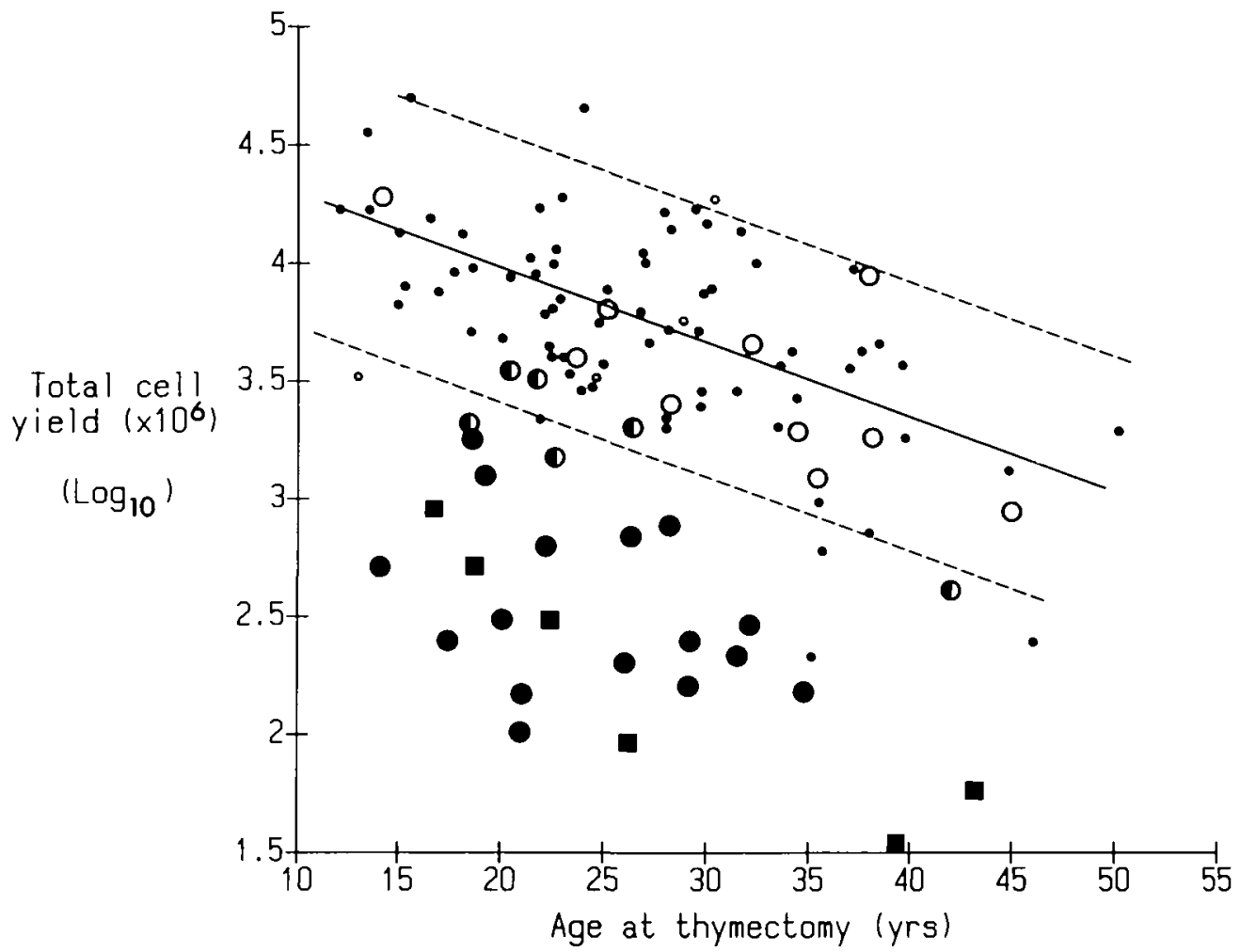

FIG. 1. Plot of total thymic cell yield $\left(\log _{10}\right)$ against age at thymectomy in pretreated and untreated cases of myasthenia gravis. The regression line for the 75 untreated myasthenics is drawn solid; the dotted lines at 1.5 standard deviations from it. Comparable points are shown for the 38 immunosuppressed patients tested. A log cell yield of $4.0=10000 \times 10^{6}$ cells. $\bullet=$ Untreated patients; in the group who received corticosteroid alone, $\mathrm{O}=$ non-depleted, $\mathrm{O}=$ intermediate, $\boldsymbol{O}=$ depleted. Group who received corticosteroids plus azathioprine $=\mathbf{\square}$.

depletion indices differed from those in the untreated cases and this difference was highly significant ( $p \ll 0.001$, Mann-Whitney U test). Second, within this group, cell depletions were strikingly variable. Ten cases fell clearly within the control range (depletion index $<17$ ) and are designated 'non-depleted'. In 16 others, cell yields were about 10-fold lower (depletion index $>32$ ) - the 'depleted' cases - and there were six remaining 'intermediates' with depletion indices of 18 to 31 . For easy reference in later Figures, these subgroups have been given distinctive symbols (Fig. 1).

Total yields of both cortical $\left(\mathrm{CD1}^{+}\right)$and medullary $\left(\mathrm{CD1}^{-}\right)$cells also declined with age in untreated cases $(r=-0.51$ and $-0.48, p<0.001)$. In nearly every pretreated case, the depletion of each of these subsets was very similar to that in Fig. 1 (not shown), and so therefore were the overall patterns. Cortical cells were more reduced than medullary, but even the latter were below the untreated range in 19 of the 22 highly depleted cases (i.e. with depletion indices $>32$ ).

Surprisingly, the depletion index correlated with neither the duration nor the total dose of corticosteroids (Table 1, bottom row). In four depleted cases, as few as 5 to 21 days of corticosteroids reduced the yields quite drastically (depletion indices $40,41,58,64$ ), whereas several non-depleted cases showed minimal effects despite being treated for much longer (Table 1). In fact the best discriminators between the subgroups proved to be the duration of 
symptoms of myasthenia gravis before the start of treatment or thymectomy, both being significantly longer in the less depleted cases (Table 1, bottom row).

\section{CORTICAL AND MEDULLARY CELL SUBSETS IN SUSPENSION}

Frequencies of cortical thymocytes $\left(\mathrm{CDI}^{+}\right)$were 60 to 75 per cent in most untreated thymus suspensions (Table 2): they were almost zero after treatment with corticosteroids plus azathioprine (0-10 per cent), and significantly reduced overall in the patients given corticosteroids alone $(p=0.0002$, Mann-Whitney $\mathrm{U}$ test), especially in the depleted cases (Table 2). Thus the single $\mathrm{CD}^{+}, \mathrm{CD}^{+}$or $\mathrm{HLA}$-class $\mathrm{II}^{+}$medullary cells were substantially enriched (see Table 3), as they were somewhat less depleted than the $\mathrm{CDl}^{+}$thymocytes.

\section{Subsets of cortical thymocytes}

The nuclear enzyme terminal deoxynucleotidyl transferase (TdT) is an independent marker for cortical thymocytes, most of which are $\mathrm{TdT}^{+}, \mathrm{CD}^{+}$in both the normal [22] and the untreated myasthenia gravis thymus. Thus of total thymus cells these constituted about 50 per cent (Table 2). This frequency was decreased about 15 -fold in the more depleted cases (depletion index $>32$ ), demonstrating that the $\mathrm{TdT}^{+}, \mathrm{CDl}^{+}$subset was one prime target of corticosteroids. By contrast, the infrequent large immature thymic blast subpopulation that expresses greater amounts of nuclear TdT with no membrane CDI (Fig. 2(a) and (c)) was

TABLE 2. Frequencies of cortical thymocyte subsets in untreated and immunosuppressed patients with myasthenia gravis: percentage of total thymic cells, expressed as median (range)

\begin{tabular}{|c|c|c|c|c|c|c|}
\hline Patient group & $\% \mathrm{CDl}^{+}$ & $n$ & $\% \mathrm{TdT}^{+}$ & $\% \mathrm{TdT}^{+} / \mathrm{CDl}^{+}$ & $\% \mathrm{TdT}^{+} / \mathrm{CDI}^{-}$ & $n$ \\
\hline Untreated & $\begin{array}{l}68.6 \\
(17-92)\end{array}$ & 64 & $\begin{array}{l}60.0 \\
(15-71)\end{array}$ & $\begin{array}{l}49.7 \\
(13-67)\end{array}$ & $\begin{array}{l}4.5 \\
(0.7-13)\end{array}$ & 8 \\
\hline \multicolumn{7}{|l|}{ Corticosteroids alone } \\
\hline Non-depleted & $\begin{array}{l}76.1 \\
(6.4-85)\end{array}$ & 10 & $\begin{array}{l}53.0 \\
(20-73)\end{array}$ & $\begin{array}{l}40.9 \\
(15-70)\end{array}$ & $\begin{array}{l}5.6 \\
(2.2-10.1)\end{array}$ & 5 \\
\hline Intermediate & $\begin{array}{l}52.0 \\
(7.8-73)\end{array}$ & 6 & $\begin{array}{l}33.0 \\
(9-75)\end{array}$ & $\begin{array}{l}18.8 \\
(5-72)\end{array}$ & $\begin{array}{l}4.4 \\
(3.0-6.6)\end{array}$ & 5 \\
\hline Depleted & $\begin{array}{l}25.8^{* * *} \\
(0-55)\end{array}$ & 15 & $\begin{array}{l}5.0^{* *} \\
(<0.5-33)\end{array}$ & $\begin{array}{c}3.1^{* *} \\
(0.5-23)\end{array}$ & $\begin{array}{l}0.6 \\
(<0.5-8.2)\end{array}$ & 5 \\
\hline Corticosteroids plus azathioprine & $\begin{array}{l}3.4^{* * *} \\
(0-19)\end{array}$ & 6 & $\begin{array}{l}2.0^{* *} \\
(<0.5-5)\end{array}$ & $\begin{array}{l}0.5^{* *} \\
(<0.5-4.3)\end{array}$ & $\begin{array}{l}0.5^{*} \\
(0.4-0.7)\end{array}$ & 3 \\
\hline
\end{tabular}

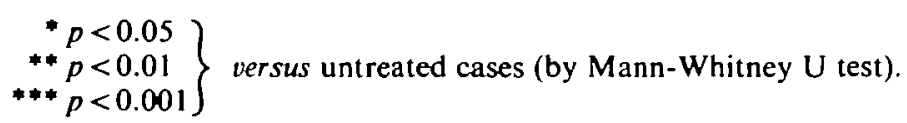

For the entire group treated with corticosteroid alone, $\mathrm{CD} 1^{+}, \mathrm{TdT}^{+}$and $\mathrm{TdT}^{+} / \mathrm{CD1}{ }^{+}$frequencies also differ from those in the untreated ( $p<0.001, p<0.05, p=0.05$ respectively).

Fresh thymic cells were stained with anti-CD1 in as many cases as possible as described in ref. 17. For labelling for TdT and CDI, cells that had been preserved in liquid nitrogen were used from all available treated cases, and from eight untreated patients of representative ages, and were double-labelled as in ref. 20. 

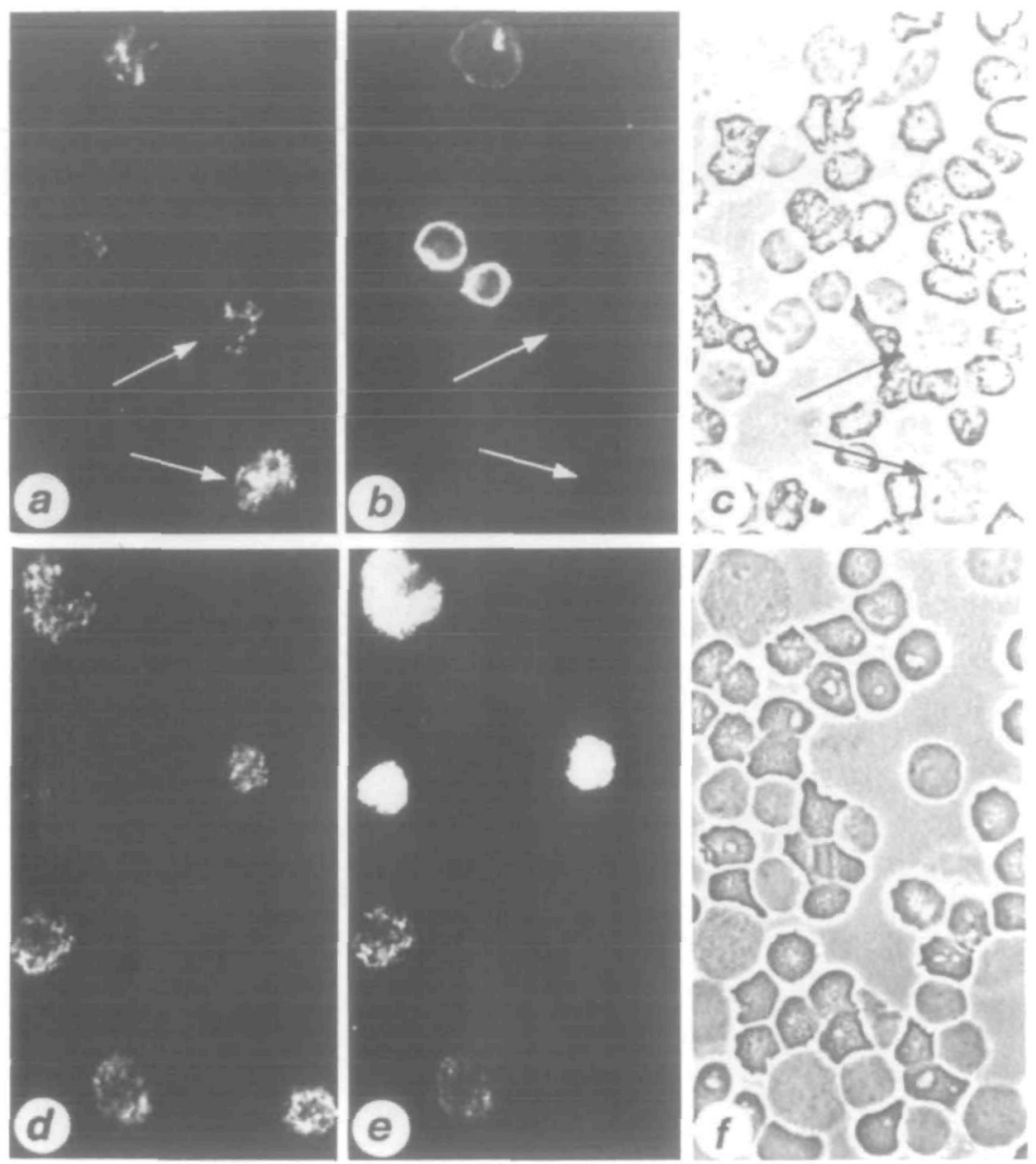

FIG. 2. Cortical thymus cell subsets in a corticosteroid-depleted patient (depletion index 63.5). (a-c) A cytocentrifuged smear was double-labelled for TdT (a, TRITC) and CDI (b, FITC). Two large TdT ${ }^{+}$, CD1 - blasts are arrowed; just above the arrows is one small $\mathrm{TdT}^{-}$and one $\mathrm{TdT}^{+}$cell, both $\mathrm{CDI}^{+} .(\mathrm{d}-$ f) Another smear was labelled for TdT (d, TRITC), and with Ki67 (e, FITC). Most of the TdT ${ }^{+}$cells, whether small or large, are $\mathrm{Ki}_{67}{ }^{+}$, and thus are still in cycle, despite the depletion after treatment with corticosteroids. (c) and (I) show phase-contrast illumination: all $\times 780$.

reduced about seven-fold in the same samples (Table 2). Its total yield was decreased too, though less than that of the $\mathrm{TdT}^{+}, \mathrm{CD}^{+}$cells.

In selected samples, we also investigated the proliferative activity of thymocyte subpopulations using the Ki67 MAb, which identifies a nuclear antigen expressed during the $\mathrm{G}_{1}, \mathrm{~S}, \mathrm{G}_{2}$ and $\mathrm{M}$ phases of the cell cycle [23]. The overall $\mathrm{Ki} 67^{+}$frequency was reduced from 49 and 52 per cent in two untreated cases to 0.2 to 10 per cent in four depleted samples. In both groups, proliferative activity was virtually confined to cortical cells, more than 95 per cent of the $\mathrm{Ki} 7^{+}$cells being $\mathrm{TdT}^{+}$. In all samples tested, the proportion of cortical $\left(\mathrm{TdT}^{+}\right)$ cells that was in cycle (i.e. $\mathrm{Ki} 67^{+}$) was similar -69 and 79 per cent in the two untreated, 38 to 78 per cent in three non-depleted, 62 to 97 per cent in three intermediate cases, and 62 per cent in one depleted patient (Fig. $2(\mathrm{~d}-\mathrm{f})$ ). Thus the depletion of total cell numbers affected the Ki67 positive (cycling) and Ki67 negative subsets of cortical cells impartially, and there 


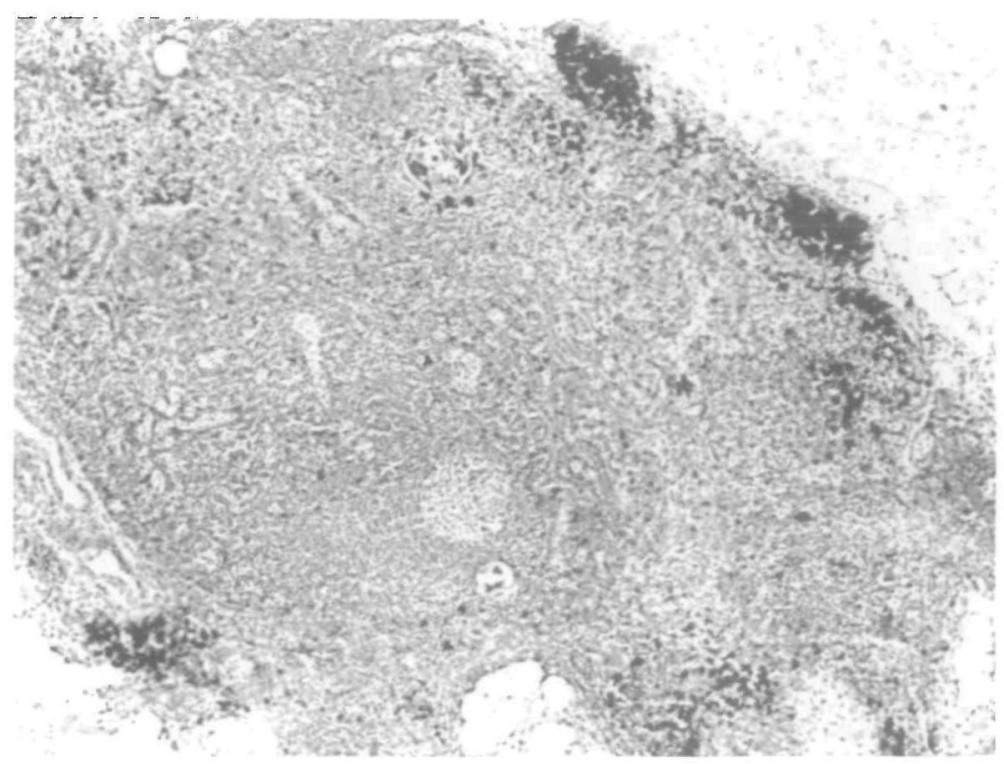

a

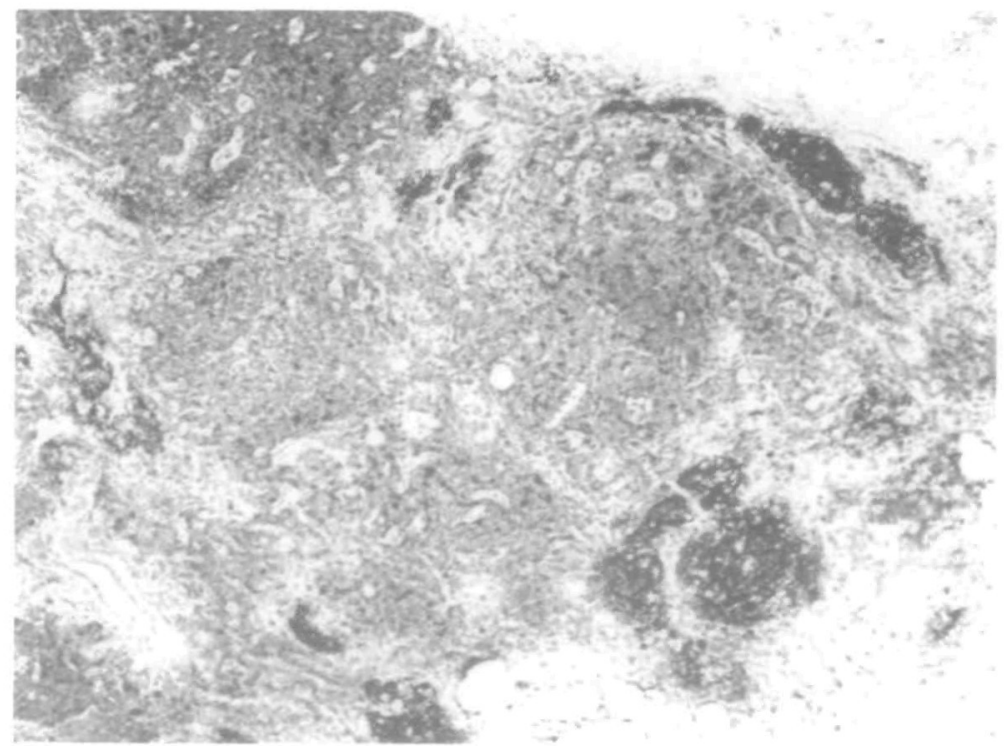

b

were no obvious cytostatic effects of corticosteroids, even in the less depleted cases. The results from untreated cases are similar to those from non-myasthenic infant thymus [20].

\section{IMMUNOHISTOLOGICAL FINDINGS}

(Our findings in the normal and in the untreated myasthenia gravis thymus are summarized in refs. 13 and 19.) From pretreated patients 13 samples were available. In three non-depleted 


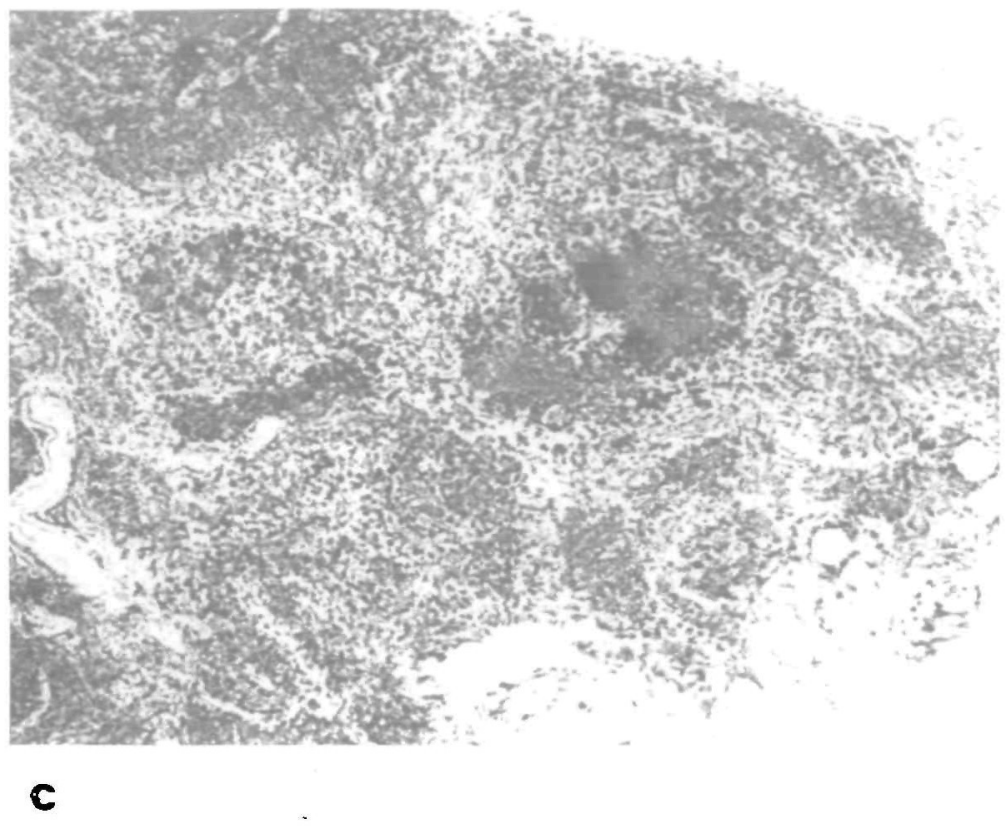

FIG. 3. Thymus from a patient treated with corticosteroids plus azathıprine (depletion index 56.5). The same area has been stained in adjacent sections. $\mathrm{CDI}^{+}$cortical areas (a) are very restricted and fragmented. Their $\mathrm{MR6}^{+}$cortical epithelial staining (b) is more extensive, so that some MR6 ${ }^{+}$patches are devoid of $\mathrm{CD} 1^{+}$cells. Anti-HLA-DR(c) also labels the T-cell zones and the small germinal centre near the centre, in addition to the cortical epithelium. All $\times 75$. Immunoperoxidase staining.

cases, immunohistology was essentially normal for the donors' ages, in spite of eightmonths' high-dose treatment in one 14-year-old male. Three further samples (depletion indices $9.5,20.5,47.5$ ) showed mild to moderate hyperplasia typical of myasthenia gravis, but only slight fragmentation/septal expansion.

The remaining samples were from four depleted patients and three given corticosteroid, plus azathioprine (depletion indices 56.5-86.5). In all seven there was some medullary hyperplasia superimposed on a series of changes not seen above. These included epithelial cysts, greatly enlarged septal/adipose areas and, above all, fragmentation, depletion and necrosis in cortical areas, leading to a gross loss of normal architecture. Thus $\mathrm{CDI}^{+}$ lymphoid cells were either confined to small scattered patches (Fig. 3(a)), or were almost completely absent, in keeping with their low frequencies in suspension (Table 2). Interestingly, these usually retained some typical network labelling for cortical epithelium with the anti-class II and especially MR6 Mabs (Figs. 3(b,c)). Staining for keratin was often weaker, and so the extent of cortical labelling was greatest with MR6 > Class II > keratin " CD1.

As a result of the depletion of cortex, the medullary epithelial areas, germinal centres and $T$-cell zones were greatly enriched and constituted almost all the remaining thymus, the epithelium sometimes showing the characteristic bands and arches [13, 19]. Furthermore, these areas usually appeared relatively undamaged, though somewhat depleted of lymphocytes. Finally, the only contribution of azathioprine that we could see (beyond those of corticosteroids alone) was that the depletions were more consistent (cf. ref. 24). 


\section{CULTURE ACTIVITIES OF THYMUS CELLS}

Anti-AChR antibody and total IgG were assayed in supernatants of thymus and blood mononuclear cells after culturing in the presence and absence of pokeweed mitogen. In untreated cases of myasthenia gravis, these thymic responses are all enriched by removing cortical thymocytes, e.g. with anti-CDI plus complement in vitro [18]; in this study the depletion of these cells by corticosteroids in vivo had a similar effect (Table 3 ). Therefore, to compare the treated and untreated cases more fairly, we have expressed the results as activity per $10^{6}$ medullary $\left(\mathrm{CDI}^{-}\right)$cells (Fig. 4(a)). We have also summed the total productivity of the entire thymus in the same cases (= production per $10^{6}$ cells $\times$ total cell yield, Fig. $4(\mathrm{~b})$ ).

\section{Anti-AChR production}

In untreated myasthenia gravis, spontaneous anti-AChR production per $10^{6}$ medullary thymic cells correlates well with the serum anti-AChR titre $(r=0.69, p<0.001$, Fig. 4(a)). Notably, in most of the pretreated cases production was clearly within the same range as the untreated, and the frequencies of producers at different serum anti-ACh R titres were similar or even higher (Fig. 4(a)).

The calculated total anti-AChR productivity of the entire thymus also correlated in untreated cases with serum anti-AChR titre, as expected $(r=0.57, p<0.001$, Fig. $4(\mathrm{~b}))$. Many of the 21 highly depleted cases fell below this typical range largely because of the cellular depopulation. By contrast, almost all the cases in the other subgroups were well within it (Fig. 4(b))

TABLE 3. Thymic B cell frequencies and culture responses in myasthenia gravis patient subsets, expressed as median (range)

\begin{tabular}{|c|c|c|c|c|c|}
\hline \multirow{3}{*}{$\begin{array}{l}\text { Patient } \\
\text { group }\end{array}$} & \multirow{2}{*}{\multicolumn{2}{|c|}{$\begin{array}{l}\text { Frequency of } \\
\text { B Cells }\end{array}$}} & \multicolumn{3}{|c|}{ Production of total $\mathrm{IgG} \dagger$} \\
\hline & & & \multirow{2}{*}{$\begin{array}{l}\text { - pokeweed } \\
\text { mitogen }\end{array}$} & \multirow{2}{*}{$\begin{array}{l}\text { + pokeweed } \\
\text { mitogen }\end{array}$} & \multirow[t]{2}{*}{$n$} \\
\hline & $\%$ & $n$ & & & \\
\hline Untreated & $\begin{array}{l}4.75 \\
(0.4-26)\end{array}$ & 62 & $\begin{array}{l}0.2 \\
(0.01-1.9)\end{array}$ & $\begin{array}{l}22.1 \\
(0.1-139)\end{array}$ & 41 \\
\hline \multicolumn{6}{|l|}{ Corticosteroids alone } \\
\hline Non-depleted & $\begin{array}{l}3.1 \\
(1.0-22.9)\end{array}$ & 9 & $\begin{array}{l}0.07 \\
(0.02-5.5)\end{array}$ & $\begin{array}{l}52.4 \\
(0.2-180)\end{array}$ & 7 \\
\hline Intermediate & $\begin{array}{l}8.3 \\
(2.9-20.9)\end{array}$ & 5 & $\begin{array}{l}1.56 \\
(0.01-4.2)\end{array}$ & $\begin{array}{l}22.7 \\
(1-131)\end{array}$ & 5 \\
\hline Depleted & $\begin{array}{l}14.4^{* * *} \\
(0.1-29.6)\end{array}$ & 14 & $\begin{array}{l}1.5 * * * \\
(0.04-7.7)\end{array}$ & $\begin{array}{l}38.0^{*} \\
(3-254)\end{array}$ & 13 \\
\hline Corticosteroids + azathıoprine & $\begin{array}{l}24.1^{* *} \\
(1.6-29.1)\end{array}$ & 6 & $\begin{array}{l}2.0 * * * \\
(0.9-5.9)\end{array}$ & $\begin{array}{l}62.0^{*} \\
(3-370)\end{array}$ & 6 \\
\hline
\end{tabular}

\footnotetext{
$\left.\begin{array}{r}{ }^{*} p<0.05 \\ { }^{* *} p<0.01 \\ { }^{* * *} p<0.001\end{array}\right\}$ versus untreated group (Mann-Whitney U test).
}

$+\mathrm{IgG}$ values are in $\mu \mathrm{g} / \mathrm{ml}$ of supernatant per $10^{6}$ cells cultured for seven days. 

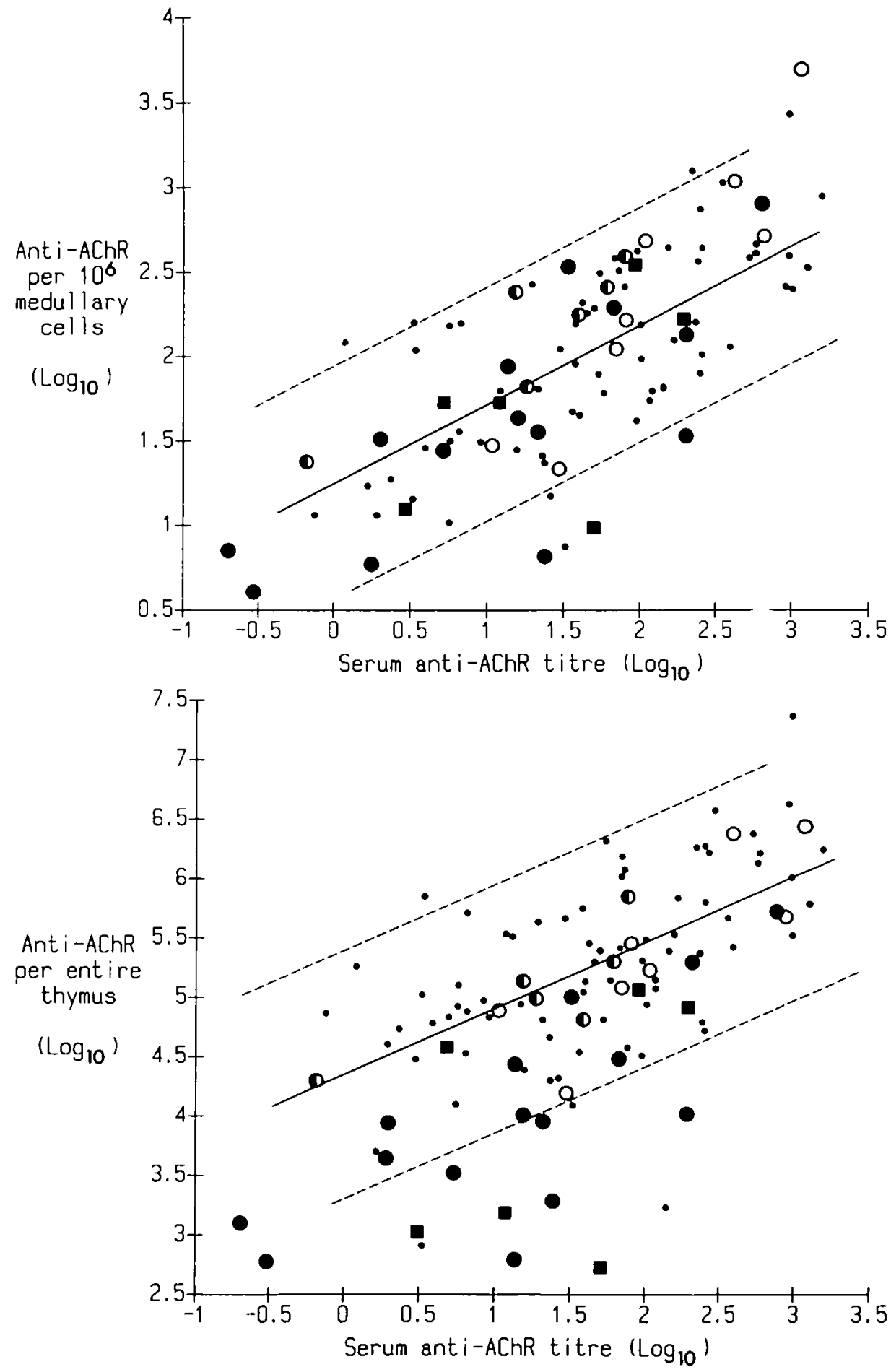

FIG. 4. (a) Plot of in-vitro anti-AChR production by thymus cells against serum anti-AChR titre in pretreated and untreated cases of myasthenia gravis. The regression line of $\log _{10}$ spontaneous antiAChR production per $10^{6}$ medullary $\left(\mathrm{CDI}^{-}\right)$thymic cells ( $\mathrm{fmol} / \mathrm{ml} /$ week) on log serum anti-ACh R titre (nMol) in 74 untreated myasthenics is drawn solid. Comparable points are shown for the 34 immunosuppressed patients tested. The background of the anti-AChR assay ranges up to $1.4 \log$ units. (b) Plot of total anti-AChR productivity against serum anti-AChR titre. The regression line of $\log _{10}$ spontaneous anti-AChR productivity per entire thymus on $\log _{10}$ serum anti-AChR titre is shown for the same patients as in (a). In (a) and (b) the dotted lines and symbols are as in Fig. 1. 


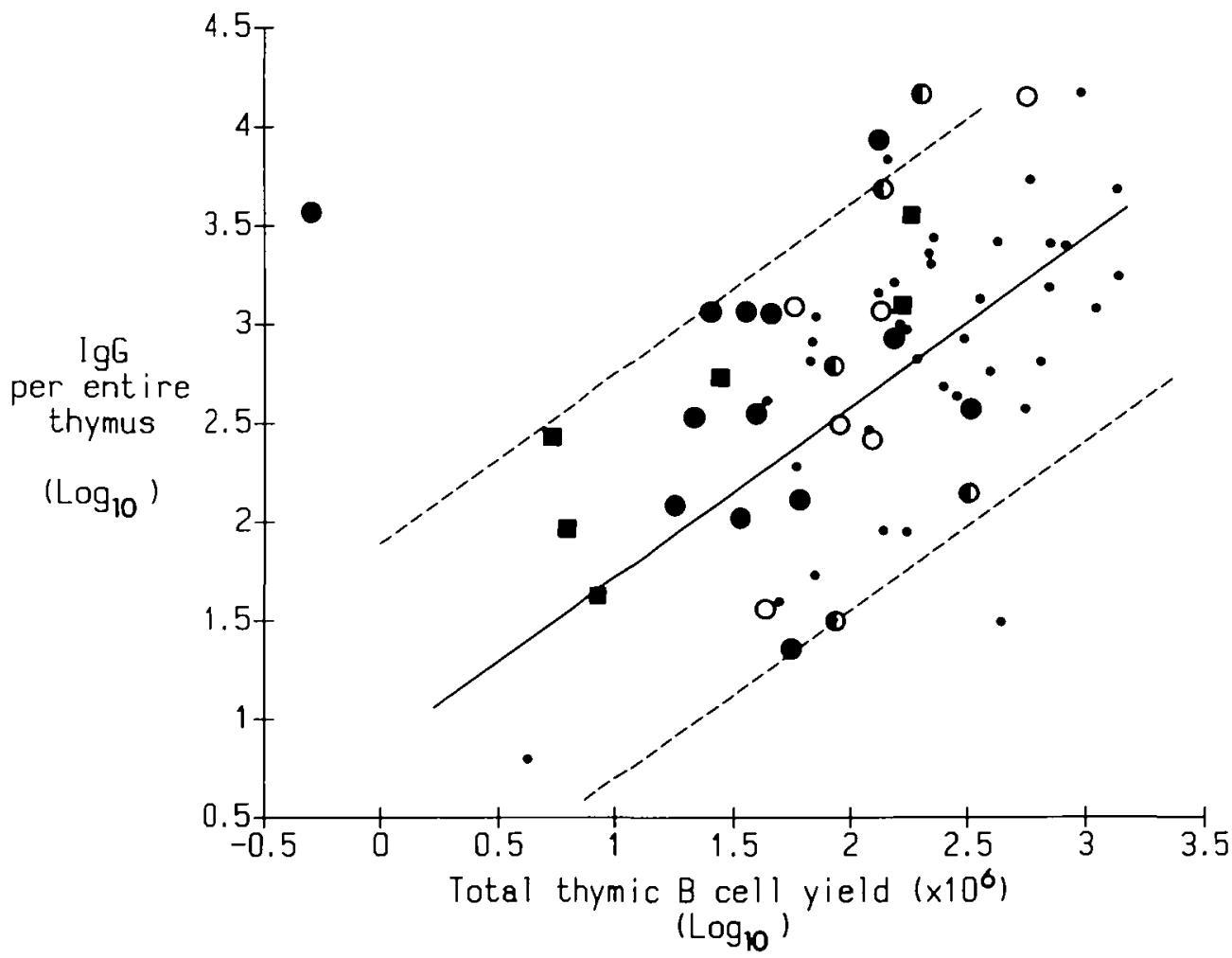

FIG. 5. Plot of $\log _{10}$ total IgG productivity against $\log _{10}$ total thymic B cell yield in pretreated and untreated cases of myasthenia gravis. The regression line for untreated patients is drawn solid, the dotted lines and symbols are as in Fig. 1.

\section{Total IgG production}

For untreated myasthenia gravis thymus cells, spontaneous total $\mathrm{IgG}$ production correlates significantly with B cell frequencies [19]. For most treated cases the values (per $10^{6}$ medullary cells) were within this 'typical' scatter and were rarely reduced (data not shown). They were predictably high in some with very numerous $B$ cells but disproportionately so in five others (Table 3) - possibly a sign of the polyclonal induction of $\operatorname{IgG}$ secretion by corticosteroids observed by others (see ref. 25 for other references). The IgG response to pokeweed mitogen was likewise rarely decreased after immunosuppression and more often enriched (Table 3).

Summed for the entire thymus, the total spontaneous $\mathrm{IgG}$ productivity correlated well with the total B cell yield in untreated cases $(r=0.62, p<0.01$, Fig. 5). After treatment, the scatter was greater: both IgG and B cell yields tended to be low in the 19 most depleted cases where only five overlapped with the untreated ones. In general, the same held true for IgG productivity stimulated by pokeweed mitogen (not shown).

\section{$T$ cell responses to $A C h R$}

Proliferative responses to Torpedo $\mathrm{AChR}$ in thymus samples from untreated myasthenics correlated with $\mathrm{CD}^{+}$cell frequencies $(r=0.61, p<0.001)$, and were highest when these were enriched in low density fractions (Fig. 6). Responses from eight of the nine pretreated cases tested were within or above this range, and had evidently been enriched by the cortical depletion (Fig. 6); total thymic responsiveness decreased with the reduction in cell yields (not shown). 


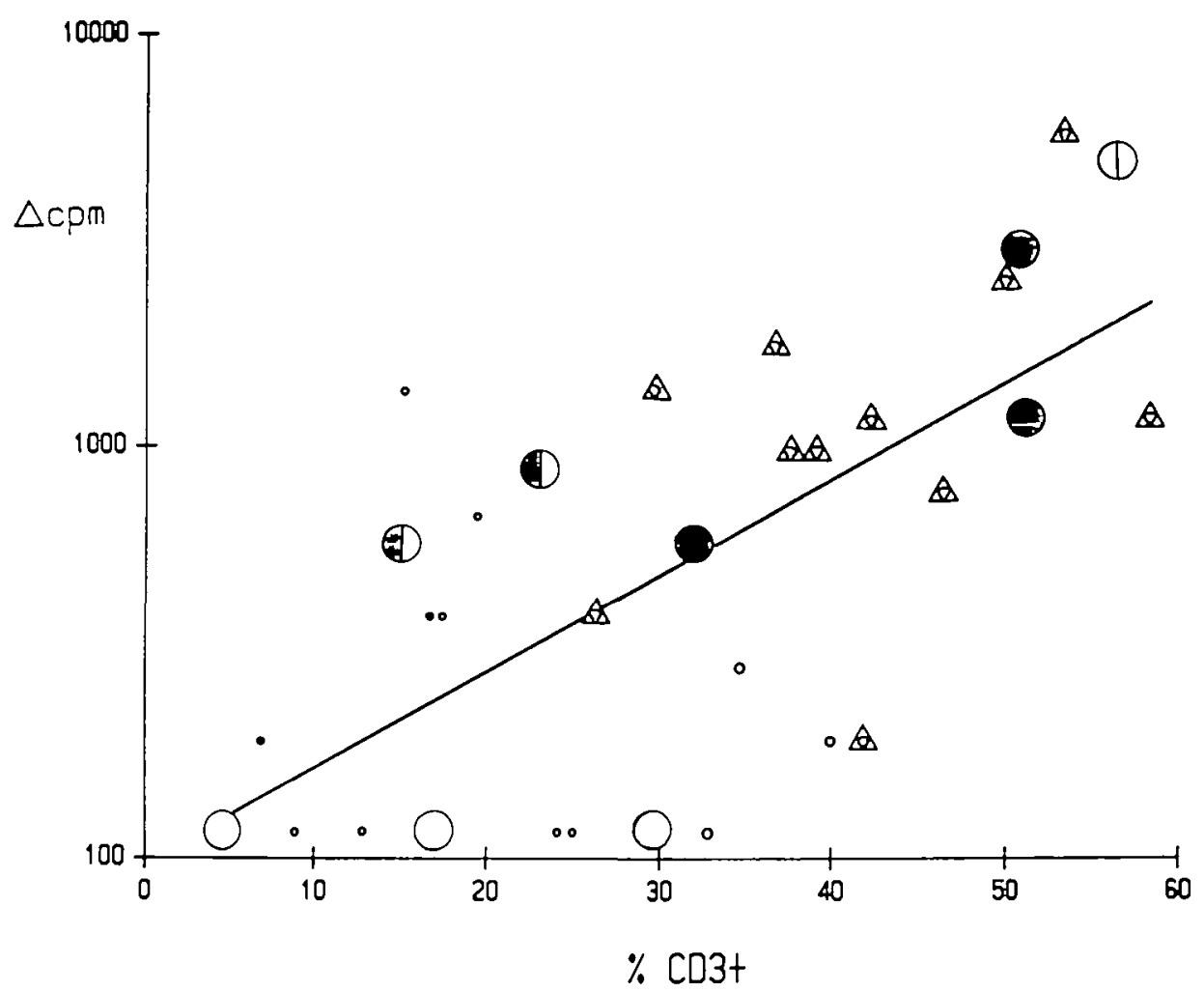

FIG. 6. T-cell proliferative responses of pretreated and untreated myasthenia gravis thymic cells to purified Torpedo AChR plotted against $\mathrm{CD}^{+}$frequency (\%). The response is expressed as cpm in cultures with $\mathrm{AChR}-\mathrm{cpm}$ in cultures without $(\triangle \mathrm{cpm})$. The regression line for the cells of untreated patients is drawn solid. o Unseparated thymic cells from untreated cases. $\Delta$ Low density thymic cells from untreated cases. Unseparated thymic cells from cases treated with corticosteroids. 0 - nondepleted; $\mathbf{O}$-intermediate; $\mathbf{O}$ - depleted.

\section{RESPONSES OF BLOOD LYMPHOCYTES}

Anti-AChR production in untreated cases was only seen in response to pokeweed mitogen, even when the serum titre exceeded $15 \mathrm{nmol}$. Among the treated cases, responders were apparently fewer, but the level of response (when positive) was comparable (not shown). Basal and pokeweed mitogen-stimulated IgG production were broadly similar in immunosuppressed and untreated cases (not shown). However, proliferative responses to Torpedo $A C h R$ were seen in only one of seven cases treated with corticosteroid compared with seven of 20 untreated (not shown).

Thus in general the major effects of therapy - especially in the thymus - were on total cell numbers and gross productivity: activity per cell was rarely reduced, except possibly with blood cells.

\section{DISCUSSION}

Effects of treatment with corticosteroids on thymic cortex and medulla

In this study, we have exploited an unusual opportunity to investigate the in-vivo effects of 
corticosteroids in man - on thymic structure, and on a range of disease-related and other cellular functions - in the autoimmune disorder myasthenia gravis. The comparisons between treated and control tissue have been made possible by our access to thymus from a large panel of untreated myasthenics. Unlike lymph nodes, the thymus is a self-contained organ, and cell yields and culture behaviour are consistent and predictable. Furthermore, our findings provide structural and functional evidence for the resistance of some patients to this therapy.

The dominant feature in many cases treated with corticosteroids was the necrosis and depletion of cortical thymocytes, one of the major effects of corticosteroids in experimental animals, where it may begin within four to 12 hours [9, 10]; it is also a feature of stress- and poison-induced thymic atrophy both in man and experimental animals (reviewed in ref. 26). In theory it could be mediated by epithelial cells which also have receptors for steroid hormones [27]. However, a direct effect on immature thymic blasts and especially on the cortical thymocytes (usually the most severely depleted cell type) seems more likely. In mice these are especially susceptible to corticosteroids in vivo $[9,10]$ and to corticosteroidmediated lysis in vitro [28]. In man they are also more metabolically sensitive to corticosteroids than peripheral $\mathrm{T}$ cells [29], and, in both thymoma [30] and non-neoplastic thymus, they are rapidly and preferentially depleted in vivo as well [31, 32 and this paper]. In view of this rapidity, direct lysis seems the simplest explanation, and this fits well with the lack of any obvious cytostatic effects; both cycling $\left(\mathrm{Ki} 67^{+}\right)$and non-cycling cells were depleted impartially, even in the less depleted cases. Corticosteroid-induced lympholysis employs a specialized metabolic pathway [33] that can presumably be activated very readily in the thymic cortex. Conceivably, however, corticosteroids might also delay or arrest cells in certain phases of the cycle, and thus exert additional cytostatic effects.

As expected, cell types in the medulla were often greatly enriched, since it was usually less severely depopulated than the cortex, as in rodents [e.g. refs. 9, 10]. Interestingly, however, absolute medullary cellularities were substantially reduced too in most of our highly depleted cases - presumably because output from the cortex $[11,12]$ was diminished. There may also have been direct actions of corticosteroids in the medulla, and/or a decreased traffic of circulating cells, which might well explain the depletion of total B cells (Fig. 5).

\section{Effects of corticosteroids on lymphoid function, and likely therapeutic actions in myasthenia gravis}

Whereas in mice germinal centres may be susceptible to corticosteroids, both they and the adjacent B cells were apparently enriched after treatment (Table 3). Like the T-cell areas, they appeared relatively undamaged not only by histological but also by functional criteria. In untreated cases of myasthenia gravis, basal and pokeweed mitogen-stimulated IgG production correlate best with germinal centre frequencies, and spontaneous anti-AChR production (and presumably T-cell proliferative responses) with the T-cell areas [19]. Expressed per $10^{6}$ cells, these four independent activities were largely unimpaired after treatment, and more often enriched. Hence, the wide range of cell types responsible for these activities - germinal centre blasts and resting B cells [19], AChR-specific plasma cells [18] and $T$ cells, as well as accessory cells-clearly persist in spite of treatment with corticosteroids. Such secondary-type responses are known to be less sensitive to corticosteroids than is the initial response to antigen [34]. That they are suppressed in vivo, and only reactivate after liberation from corticosteroids in vitro, seems unlikely in the light of current knowledge of the effects of alternate day treatment [35].

Thus another major conclusion from our results is that this immunosuppressive therapy 
mainly affected cell numbers rather than function per surviving cell. This presumably applied in the periphery as well as in the thymic medulla, since the B lineage cells in the myasthenia gravis thymus are representative of the entire repertoire in the patient $[15,36]$. This may seem paradoxical since, in the serum, anti-AChR levels apparently fall more strikingly during treatment than does total $\operatorname{IgG}[37,38]$, and one might expect a global reduction in cell numbers to affect both impartially. Perhaps additionally corticosteroids may selectively affect activated cells, for example by inhibiting IL2 production [39] or the response to it. Such immunoregulatory actions might explain how the autoimmune response in myasthenia gravis comes to be preferentially reduced, as it presumably is continually being reactivated by recurrent release of $\mathrm{AChR}$ or $\mathrm{AChR}$-antibody complexes from damaged endplates. $\mathrm{By}$ contrast, serum IgG depends largely on plasma cells (e.g. in bone marrow and spleen [38]) which may be less susceptible to corticosteroids. Finally, corticosteroids can affect the complement system [40], and may also act in myasthenia gravis by reducing the endplate damage.

\section{Interpatient variation in sensitivity to corticosteroids}

A third major finding has been the great variability in effects between patients, something regularly seen in clinical practice (e.g. ref. 37), but seldom discussed. Most strikingly, the depletion indices correlated with neither the duration nor the total dose of corticosteroids. We cannot wholly exclude non-compliance in individual patients, but it seems unlikely in as many as 10 (or even 16) out of 32 . In fact, our findings agree very well with an important recent series of reports on steroid resistance of human lymphocytes assessed in vitro. In about 40 per cent of normal subjects, phytohaemagglutinin-stimulated blood T cells release IL 2 at an unusually high rate that is less easily suppressed by in-vitro corticosteroids [41]. These rates scarcely overlap between susceptible and resistant subjects who remain true to type over a period of months or years. Moreover, renal transplant recipients who are steroidsusceptible in this or similar assays are much more likely to have a functioning kidney three to six months later $[3,4]$. These individual differences thus affect responses of mature $T$ cells both in vivo and in culture, and our data suggest that they also apply to very immature precursor $\mathrm{T}$ cells in the thymic cortex.

These differences might have a genetic basis, in view of known differences in sensitivity to corticosteroids between species [42], mouse strains [43], and patients of different HLA types (ref. 44; not evident in our 11 HLA typed cases). As the best discriminators between the subgroups were the durations of symptoms of myasthenia gravis before thymectomy or immunosuppression, another possibility is that the persistently hyperplastic myasthenia gravis thymus is more resistant to corticosteroids. Perhaps more likely, patients with longstanding myasthenia gravis may only be selected for thymectomy after steroid therapy has failed, and our series may be enriched for such cases.

Whatever the explanation, this variation in sensitivity must significantly influence the effective dose of corticosteroids, normally determined empirically for each patient. Three further practical conclusions from this study are that (i) corticosteroids in myasthenia gravis do not always destroy the thymus which may still therefore warrant removal, (ii) the main therapeutic action of corticosteroids in myasthenia gravis is on the peripheral immune system, since they may be very effective in cases who have had previous thymectomy, and (iii) the depletion of both cortical and medullary $T$ cells is likely to be a major disadvantage of the intensive treatment with corticosteroids often used after bone marrow transplantation, since it may prevent proper $\mathrm{T}$-cell reconstitution via the thymus, especially in steroid-sensitive subjects. 


\section{ACKNOWLEDGEMENTS}

This work was supported by grants from the Sir Jules Thorn Charitable Trust and the Medical Research Council. N.S. was funded by the Deutsche Forschungsgemeinschaft.

We thank Dr T. J. Bowley, Ms L. R. Calder, Ms N. Nagvekar, Mr D. S. Pole, Mr A. Salam and Ms J. M. Workman for their expertise, and Dr K. B. Walker for invaluble advice on the typescript. We are greatly indebted to Mr M. Sturridge, FRCS, and Dr L. Loh, FFA.RCS, for help in obtaining samples, to many colleagues who referred patients to us, and to $\mathrm{Dr}$ M. A. Ritter and Professor A. J. McMichael for generous gifts of Mabs.

\section{REFERENCES}

1. Newsom-Davis J. Diseases of the neuromuscular junction. In: Asbury AK, Mackhann GM, McDonald WI, eds. Diseases of the nervous system. Philadelphia: Saunders, 1986: 269-282.

2. Buckingham JM, Howard FM, Bernatz PE, et al. The value of thymectomy in myasthenia gravis. Ann Surg 1976; 184: 453-458.

3. Dumble LJ, Macdonald IM, Kincaid-Smith P, Clunie GJA. Correlation between ADCC resistance to in vitro steroid and renal allograft failure. Transplant Proc 1981; 13: 1569-1571.

4. Langhoff $E$, Ladefoged J. The impact of high lymphocyte sensitivity to glucocorticoids on kidney graft survival in patıents treated with azathioprine and cyclosporine. Transplantation 1987; 43: 380-384.

5. Vincent A. Immunology of acetylcholine receptor in relation to myasthenia gravis. Physiol Rev 1980; 60: 756-824.

6. Castleman B, Norris EH, The pathology of thymus gland in myasthenia gravis. A study of 35 cases. Medicine (Baltimore) 1949; 28: 27-58.

7. Wekerle H, Ketelsen U-P. Intrathymic pathogenesis and dual genetic control of myasthenia gravis. Lancet 1977; 1: 678-680.

8. Schluep M, Willcox N, Vincent A, Dhoot GK, Newsom-Davis J. Acetylcholine receptors in human thymic myoid cells in situ: an immunohistological study. Ann Neurol 1987; 22: 212-222.

9. Ishidate $M$, Metcalf $D$. The pattern of lymphopoiesis in the mouse thymus after cortisone administration or adrenalectomy. Aust J Exp Biol Med Sci 1963; 41: 637-649.

10. De Sousa M, Fachet $J$. The cellular basis of the mechanism of action of cortisone acetate on contact sensitivity to oxazolone in the mouse. Clin Exp Immunol 1972; 10: 673-684.

11. Fowlkes BJ, Schwartz RH, Pardoll DM. Deletion of self-reactive thymocytes occurs at a $\mathrm{CD}^{+} 8^{+}$ precursor stage. Nature (London) 1988; 334: 620-623.

12. Janossy G, Campana D. Akbar A. Kinetics of T lymphocyte development. Curr Top Pathol 1989; 79: 59-99.

13. Bofill M, Janossy G, Willcox N, Chilosi M, Trejdosiewicz LK, Newsom-Davis J. Microenvironments in the normal thymus and the thymus in myasthenia gravis. Am J Pathol 1985; 119:462-473.

14. Scadding GK, Vincent A, Newsom-Davis J, Henry K. Acetylcholine receptor antibody synthesis by thymic lymphocytes: correlation with thymic histology. Neurology (NY) 1981; 31: 935-943.

15. Newsom-Davis J, Willcox N, Schluep M, et al. Immunological heterogeneity and cellular mechanisms in myasthenia gravis. Ann NY Acad Sci 1987; 505: 12-26.

16. Thomas JA, Willcox N, Newsom-Davis J. Immunohistological studies of the thymus in myasthenia gra vis. Correlation with clinical state and thymocyte culture responses. J Neuroimmunol 1982; 3: 319-335.

17. Willcox HNA, Newsom-Davis J, Calder L. Greatly increased autoantibody production in myasthenia gravis by thymocyte suspensions prepared with proteolytic enzymes. Clin Exp Immunol 1983; 54: 378-386.

18. Willcox HNA, Newsom-Davis J, Calder L. Cell types required for anti-acetylcholine receptor antibody synthesis by cultured thymocytes and blood lymphocytes in myasthenia gravis. Clin Exp Immunol 1984; 58: 97-106.

19. Schluep M, Willcox N, Ritter MA, Newsom-Davis J, Larché M, Brown AN. Myasthenia gravis thymus: clinical, histological and culture correlations. J Autoimmunol 1988; 82: 1295-1300.

20. Campana D, Janossy G. Proliferation of normal and malignant human immature lymphoid cells. Blood 1988; 71: 1201-1210. 
21. Harcourt GC, Sommer N, Rothbard J, Willcox HNA, Newsom-Davis J. A juxta-membrane epitope on the human acetylcholine receptor recognised by $\mathbf{T}$ cells in myasthenia gravis. $\mathrm{J}$ Clin Invest 1988; 82: 1295-1300.

22. Bradstock KF, Janossy G, Pizzolo G, et al. Subpopulations of normal and leukemic human thymocytes: an analysis with the use of monoclonal antibodies. J Natl Cancer Inst 1980; 65: 33-42.

23. Gerdes J, Lemke H, Baisch H, Wacker H-H, Schwab U, Stein H. Cell cycle analysis of a cell proliferation-associated human nuclear antigen defined by the monoclonal antibody Ki67. J Immunol 1984; 133: 1710-1715.

24. Schalke BCG, Mertens H-G, Kirchner T, Wegener S, Müller-Hermelink HK. Long-term treatment with azathioprine abolishes thymic lymphoid follicular hyperplasia in myasthenia gravis. Lancet 1987; 2: 682.

25. Cupps TR, Edgar LC, Thomas CA, Fauci AS. Multiple mechanisms of B cell immunoregulation in man after administration of in vivo corticosteroids. J Immunol 1984; 132: 170-175.

26. Dourov N. Thymic atrophy and immune deficiency in malnutrition. Curr Top Pathol 1986; 75: 127-150.

27. Dardenne M, Itoh T, Homo-Delarche F. Presence of glucocorticoid receptors in cultured thymic epithelial cells. Cell Immunol 1986; 100: 112-118.

28. Claman HN, Moorhead JW, Benner WH. Corticosteroids and lymphoid cells in vitro. I. Hydrocortisone lysis of human, guinea pig and mouse thymus cells. J Lab Clin Med 1971; 78: 499507.

29. Homo-Delarche F. Glucocorticoid receptors and steroid sensitivity in normal and neoplastic human lymphoid tissues: a review. Cancer Res 1984; 44: 431-437.

30. Willcox N, Schluep M, Ritter MA, Schuurman HJ, Newsom-Davis J, Christensson B. Myasthenic and nonmyasthenic thymoma: an expansion of a minor cortıcal epithelial cell subset? Am J Pathol 1987; 127: 447-460.

31. Craven C, Reddy PK, Ringel SP, Rutherford RB. Effect of corticosteroids on the thymus in myasthenia gravis. Muscle and Nerve 1981; 4: 425-428.

32. Berrih S, Safar D, Levasseur P, Gaud C, Bach J-F. The in vivo effects of corticosteroids on thymocyte subsets in myasthenia gravis. J Clin Immunol 1984; 4: 92-97.

33. Munck A, Crabtree GR. Glucocorticoid-induced lymphocyte death. In: Bowen ID, Lockshin RA, eds. Cell death in biology and pathology. London: Chapman \& Hall, 1981; 329-359.

34. Bach J-F, Strom TB. The mode of action of immunosuppressive agents. Amsterdam: Elsevier, 1985.

35. Fauci AS, Dale DC. Alternate day prednisone therapy and human lymphocyte subpopulations. J Clin Invest 1975; 55: 22-32.

36. Heidenreich F, Vincent A, Willcox N, Newsom-Davis J. Anti-acetylcholine receptor antibody specificities in serum and in thymic cell culture supernatants from myasthenia gravis patients. Neurology $1988 ; 38: 1784-1788$.

37. Tindall RSA. Humoral immunity in myasthenia gravis: effect of steroids and thymectomy. Neurology 1980; 30: 554-557.

38. McMillan R, Longmire R, Yelenosky R. The effect of corticosteroids on human IgG synthesis. J Immunol 1976; 116: 1592-1595.

39. Cupps TR, Fauci AS. Corticosteroid-mediated immunoregulation in man. Immunol Revs 1982; 65: 133-155.

40. Gewurz H, Wernick PR, Quie PG, Good RA. Effects of hydrocortisone succinate on the complement system. Nature 1965; 208: 755-757.

41. Walker KB, Potter JM, House AK. Interleukin 2 synthesis in the presence of steroids: a model of steroid resistance. Clin Exp Immunol 1987; 68: 162-167.

42. Claman H. Corticosteroids and lymphoid cells. N Engl J Med 1972; 287: 388-397.

43. Pla M, Zakany J, Fachet J. $\mathrm{H}_{2}$ influence on corticosteroid effects on thymus cells. Folia Biol (Praha) 1976; 22: 49-50.

44. Becker B, Shin DH, Palmberg PF, Waltman SR. HLA antigens and corticosteroid response. Science 1976; 194: 1427-1428. 